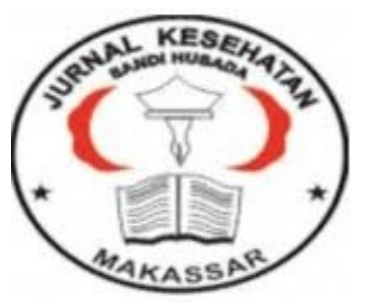

\author{
Jurnal Ilmiah Kesehatan Sandi Husada \\ hhttps://akper-sandikarsa.e-journal.id/JIKSH \\ Vol 11, No, 1, Juni 2020, pp;183-189 \\ p-ISSN: 2354-6093 dan e-ISSN: 2654-4563 \\ DOI: $10.35816 /$ jiskh.v10i2.245
}

\title{
Leukosit dan Kadar Bilirubin Total pada Ikterus Obstruktif yang Disebabkan oleh Tumor Pankreas
}

The Leukocytes and Total Bilirubin Levels in Obstructive Jaundice Caused by Pancreatic Tumors

Liqva Nurul Fadhilah

${ }_{1}^{1}$ Pendidikan Dokter, Fakultas Kedokteran, Universitas Malahayati

\section{Artikel info}

Artikel history:

Received;20 Maret 2020

Revised:26 Maret 2020

Accepted;28 Maret 2020

\begin{abstract}
Abstrak
Kanker pankreas merupakan tumor yang membahayakan yang terjadi dalam waktu yang lama dan berkembang cepat sebelum menunjukkan gejala klinis. Mayoritas penderita kanker pankreas awalnya tidak menunjukkan gejala yang spesifik sehingga sering terlambat didiagnosis, dan termasuk salah satu kanker yang prognosisnya paling buruk. Tujuan : Mengetahui hubungan leukosit dan kadar bilirubin total pada penderita ikterus obstruktif yang disebabkan oleh tumor pankreas di Rumah Sakit Abdul Muluk tahun 20172019. Metode :Penelitian ini bersifat deskriptif analitik dengan pendekatan cross sectional. Teknik pengambilan sampel yang digunakan yaitu total sampling. Data kejadian tumor pankreas diperoleh dari data sekunder dengan hasil rekam medik yang terdiagnosa tumor pankreas serta dianalisis berdasarkan analisa univariat untuk mengetahui distribusi frekuensi dan analisa bivariat dengan menggunakan uji korelasi spearrman's. Hasil analisis statistik menggunakan uji korelasi spearman's yang menunjukkan hasil p-value sebesar 0,024 dan 0.047 (p-value $<0,05$ ) yang berarti bahwa terdapat hubungan yang bermakna antara leukosit dan kadar bilirubin total pada penderita ikterus obstruktif yang disebabkan oleh tumor pankreas di Rumah Sakit Abdul Moeloek Tahun 2017-2019. Kesimpulan : Ada hubungan leukosit dan kadar bilirubin total pada penderita ikterus obstruktif yang disebabkan oleh tumor pankreas di Rumah Sakit Abdul Muluk tahun 20172019.
\end{abstract}

Abstract
Pancreatic cancer is a dangerous tumor which occurs
protractedly and develops rapidly before showing its clinical
symptoms. Initially, most of patients with pancreatic cancer
do not indicate specific symptoms thus, it lead to late
diagnosed, an advanced stage and this is one of the worst
prognosis cancers. Objective to determine the correlation
between leukocytes and total bilirubin levels in obstructive


Keywords:

Leukosit ;

Bilirubin Total;

Ikterus Obstruktif;

Tumor pankreas;

jaundice patients that caused by pancreatic tumors an Abdul Muluk hospital in 2017-2019. Methods: Analytic descriptive with cross sectional approach was used in this present research. Total sampling was used as the sampling technique. The data regarding pancreatic tumor were obtained from secondary data with the results of medical recorded diagnosed with pancreatic tumors, and was analyzed on a univariate basis to determine the distribution frequency and bivariate by using Spearman's correlation test. Result of statistical analysis by using the Spearman's correlation test showed p-value of 0,024 and0,047(pvalue $<0,05)$ which means that there was a significant relationship between leukocytes and total bilirubin levels in obstructive jaundice patients that caused by pancreatic tumors at Abdul Moeloek hospital in 2017-2019. Conclusion There is a correlation between leukocytes and total bilirubin levels in obstructive jaundice patients that caused by pancreatic tumors at Abdul Muluk hospital in 2017-2019.

\section{Coresponden author:}

Email: liqva23@gmail.com

artikel dengan akses terbuka dibawah lisensi CC BY -4.0

\section{Pendahuluan}

Ikterus obstruktif akibat keganasan merupakan kolestasis yang sebagian besar disebabkan karsinoma kaput pankreas dan sebagian kecil disebabkan kolangiokarsinoma (Oddsdottir, et al., 2005). Karsinoma pankreas disebut sebagai keganasan yang langka karena insidensinya yang rendah. Sayangnya, meskipun dapat didiagnosis awal, namun angka mortalitasnya tinggi. Hal ini menjelaskan bahwa meskipun insidensinya rendah, karsinoma pankreas menduduki peringkat ke 8 dunia untuk mortalitasnya (Lowenfels $A B$, Maisonneuve P, 2006). Keganasan kaput pankreas dan duktus bilier secara klinis tidak tampak sampai muncul tanda dan gejala ketika tumor telah meluas dan dalam stadium lanjut yang sulit untuk diterapin. (Harris, H., 2001).

Pada ikterus obstruktif, kemampuan produksi bilirubin adalah normal, namun bilirubin yang dibentuk tidak dapat dialirkan ke dalam usus melalui sirkulasi darah oleh karena adanya suatu sumbatan (obstruksi). Ikterus obstruksi dapat ditemukan pada semua kelompok umur, tetapi bayi baru lahir dan anak-anak lebih rentan mengalami ikterus obstruksi karena struktur hepar yang masih immatur. Bayi-bayi yang lahir prematur, BBLR, dan riwayat sepsis,serta riwayat mendapat nutrisi parenteral dalam waktu lama meningkatkan risiko terjadinya ikterus obstruksi (Hisham et al., 2007). Kasus ikterus obstruksi post-hepatik terbanyak mengenai usia 50 - 59 tahun 29,3\%. Kasus ikterus obstruksi post-hepatik dapat mengenai jenis kelamin laki-laki dan perempuan dimana jenis kelamin laki-laki sebanyak 65,9\%. Hatfield et al, melaporkan bahwa kasus ikterus obstruktif terbanyak adalah 70\% karena karsinoma kaput pankreas, $8 \%$ pada batu common bile duct, dan $2 \%$ adalah karsinoma kandung empedu. Adapun angka kejadian ikterus obstruksi kausa Atresia Bilier (AB) di USA sekitar 1:15.000 kelahiran, dan didominasi oleh pasien berjenis kelamin wanita (Ringoringo, 1990).

Tumor eksokrin pankreas pada umumnya berasal dari sel duktus dan sel asiner. Sekitar 90\% merupakan tumor ganas jenis adenokarsinoma duktus pankreas, dan sebagian besar 
kasus (70\%) lokasi kanker adalah pada kaput pankreas. Pada stadium lanjut, kanker kaput pankreas sering bermetastasis ke duodenum, lambung, peritoneum, hati, dan kandung empedu. Pasien dengan lesi di kaput pankreas biasanya terjadi peningkatan bilirubin dan alkalin fosfat. Pemeriksaan laboratorium rutin biasanya normal dan tumor marker yang dilakukan adalah CEA dan CA 19-9. Dimana terjadinya peningkatan pada kedua tumor marker tersebut. Tumor marker Ca 19-9 biasanya paling banyak digunakan karena mempunyai sensitivitas dan spesivitas tinggi (80\%dan 60-70\%) (Darmawan, 2011). Antigen karbohidrat serum 19-9 (CA 19-9) sering digunakan untuk diagnosis dan penilaian prognosis dari neoplasma pankreatobilier. Kadar CA 19-9 >100 U/mL sering menandai adanya penyakit keganasan, terutama sadium awal kanker pankreas. Spesifitas dari kadar CA 19-9 >1000 U/mL untuk kanker pankreas ialah 99\%. Namun, kadar CA 19-9 setinggi $>1000 \mathrm{U} / \mathrm{mL}$ sering juga ditemukan pada beberapa penyakit jinak, seperti batu duktus biliaris komunis, kolangitis akut, pankreatitis akut, diabetes, dan sirosis hepatis.

Tumor pankreas adalah tumor yang berasal dari jaringan eksokrin dan endokrin pankreas. Berdasarkan histopatologinya, tumor pankreas dibagi menjadi tumor jinak dan tumor ganas. Menurut klasifikasi WHO tumor primer eksokrin pankreas dibagi 3 bagian yaitu jinak, borderline, dan ganas. Tumor eksokrin pankreas pada umumnya berasal dari sel duktus dan sel asiner. Sekitar 90\% tumor pankreas merupakan tumor ganas jenis adenokarsinoma duktus pankreas atau yang disingkat kanker pankreas. (Padmomartono, 2009). Prevalensi pasien kanker pankreas di dunia yang bertahan hidup selama lima tahun adalah 4.1 per 100.000. Kanker pankreas jarang terjadi pada usia $<40$ tahun dan sering terjadi pada usia 60-80 tahun dan lebih sering ditemukan pada pria dibandingkan wanita dengan perbandingan 1,2-1,5: 1 . Insidensi kanker pankreas adalah 1-10 kasus per 100.000 dan umumnya meningkat pada negara-negara berkembang. (Ryan, 2014). Di Amerika Serikat, kanker pankreas masuk dalam peringkat keempat penyebab kematian setelah kanker paru, prostat, dan kolorektal.

Pada tahun 2008 insidensi kanker pankreas di Amerika Serikat adalah 37.700 kasus dan 34.300 diantaranya meninggal karena penyakit ini. Survival rate penderita kanker pankreas yang bertahan selama lima tahun $<5 \%$. (Hidalgo, 2010). Kanker pankreas menduduki peringkat ke-12 yang paling sering di dunia dan termasuk dalam peringkat keempat di Amerika Serikat. Kanker ini lebih sering terjadi pada pria dibandingkan wanita (1,5: 1) dan juga lebih sering pada kulit hitam dibandingkan berkulit putih. Berisiko dua atau tiga kali jika memiliki saudara yang menderita kanker pankreas (Brunicardi, 2015) . Hampir 80\% terjadi pada usia 60-80 tahun. Data di Amerika Serikat pada tahun 2007 menunjukkan kanker pankreas penyebab kematian terbesar pada pria dan wanita $>40$ tahun dengan resiko tertinggi pada usia 60-79 tahun dan jarang dijumpai pada usia < 50 tahun (Darmawan dan Simadibrata, 2011). Berdasarkan Surveillance Epidemiology and End Results Program (SEER) dan data National Center for Health Statistics menunjukkan bahwa insidensi kanker pankreas pada pria dan wanita meningkat 1,4\% tahun 2000-2009, kemudian data 2011/2012 menunjukkan tingkat kematian meningkat1,7\% (Steer,2008).

Di Indonesia, kanker pankreas tidak jarang ditemukan dan merupakan tumor ganas ketiga terbanyak pada pria setelah tumor paru dan tumor kolon. Insidensi tertinggi terjadi pada usia 50-60 tahun. Namun, data kepustakaan kanker pankreas di Indonesia masih sangat sedikit. Data di RSUP Dr. Kariadi Semarang pada tahun 1997-2004 terdapat 53 kasus. Penelitian epidemiologi menunjukkan adanya hubungan kanker pankreas dengan beberapa faktor eksogen (lingkungan) dan faktor endogen pasien. Faktor eksogen meliputi kebiasaan merokok, diet tinggi lemak, alkohol, kopi, zat karsinogen industri dan faktor endogen yaitu usia, penyakit pankreas (pankreatitis kronik dan diabetes mellitus) dan mutasi genetik.hampir 60-70\% kanker pankreas lokasinya di kaput pankreas, 20-25\% 
berada di korpus dan kauda pankreas. Simptom dan gejala klinisnya berhubungan dengan lokasi kanker. Manifestasi yang paling sering dikeluhkan pasien yaitu, nyeri abdomen, berat badan menurun, anoreksia, dan juga ikterus .Sekitar 50\% pasien kanker pankreas memiliki penyakit diabetes (Padmomartono, 2009).

\section{Metode}

Penelitian ini merupakan penelitian analatik observasional dengan pendekatan cross sectional. Pengambilan sampel pada penelitian ini menggunakan metode total sampling dan didapatkan sampel sebanyak 40 orang. Data kejadian tumor pankreas diperoleh dari data sekunder dengan hasil rekam medik pasien tumor pankreas di Rumah Sakit Abdul Moeloek Provinsi Lampung tahun 2017-2019. Penelitian ini dianalisis berdasarkan univariat untuk mengetahui distribusi frekuensi dan bivariat dengan menggunakan uji korelasi spearman's.

\section{Hasil dan pembahasan}

Tabel 1 Analisis Leukosit Pada Penderita Ikterus Obstruktif Yang Disebabkan Oleh Tumor Pankreas di Rumah Sakit Abdul Moeloek Tahun 2017-2019

\begin{tabular}{lllrr}
\hline & & Diagnosa & Leukosit \\
\hline Spearman's rho & Diagnosa & Correlation Coefficient & 1,000 &, $316^{*}$ \\
& & Sig. (2-tailed) & &, 047 \\
& & N & 40 & 40 \\
\cline { 2 - 5 } & leukosit & Correlation Coefficient &, $316^{*}$ & 1,000 \\
& & Sig. (2-tailed) &, 047 & \\
& & $\mathrm{~N}$ & 40 & 40 \\
\hline
\end{tabular}

Berdasarkan uji korelasi spearmen diperoleh $p$-value $0,047(\leq 0,05)$ sehingga ha diterima. Hal ini menunjukkan bahwa ada korelasi yang baik antar kadar leukosit dengan kejadian tumor pankreas dan juga menampilkan nilai korelasi data yaitu 0,316. Maka dapat disimpulkan bahwa terdapat hubungan yang bermakna antara kadar leukosit dengan kejadian tumor pankreas di Rumah Sakit Abdul Moeloek tahun 2017-2019.

Tabel 2. Analisis Kadar Bilirubin Total Pada Penderita Ikterus Obstruktif yang disebabkan Oleh Tumor Pankreas di Rumah Sakit Abdul Moeloek Tahun 2017-2019

\begin{tabular}{|c|c|c|c|c|}
\hline & & & Bilirubin total & diagnosa \\
\hline \multirow{5}{*}{ Spearman's rho } & Bilirubin total & $\begin{array}{l}\text { Correlation } \\
\text { Coefficient }\end{array}$ & 1,000 & ,357* \\
\hline & & Sig. (2-tailed) & & ,024 \\
\hline & & $\mathrm{N}$ & 40 & 40 \\
\hline & Diagnosa & $\begin{array}{l}\text { Correlation } \\
\text { Coefficient } \\
\text { Sig. (2-tailed) }\end{array}$ & $\begin{array}{c}357^{*} \\
, 024\end{array}$ & 1,000 \\
\hline & & $\mathrm{N}$ & 40 & 40 \\
\hline
\end{tabular}

Berdasarkan uji korelasi spearmen diperoleh $p$-value $0,024(\leq 0,05)$ sehingga ha diterima. Hal ini menunjukkan bahwa ada korelasi yang baik antar kadar bilirubin total dengan kejadian tumor pankreas dan juga menampilkan nilai korelasi data yaitu 0,357. Maka dapat disimpulkan bahwa terdapat hubungan yang bermakna antara kadar bilirubin total dengan kejadian tumor pankreas di Rumah Sakit Abdul Moeloek tahun 2017-2019. Berdasarkan uji korelasi spearmen diperoleh $p$-value $0,047(\leq 0,05)$ sehingga ha diterima. 
Maka dapat disimpulkan bahwa terdapat hubungan yang bermakna antara kadar leukosit dengan penderita ikterus obstruktif yang disebabkan oleh tumor pankreas di Rumah Sakit Abdul Moeloek tahun 2017-2019. Dari hasil penelitian sebagain besar kadar leukosit meningkat dari nilai normal, diketahui leukosit atau sel darah putih berfungsi untuk melawan berbagai penyakit infeksi dan sebagai bagian dari sistem kekebalan tubuh. Hidup sel leukosit tidak lama dan jumlahnya diperlukan di tempat inflamasi dipertahanankan oleh infurk sel-sel baru dari persediaan sumsum tulang. Pada infeksi akut neutrofil dalam sirkulasi dapat meningkat dengan segera, peningktan tersebut disebabkan oleh migrasi neutrofil ke sirkulasi dari sumsum tulang dan persediaan marginal intravaskular.

Ikterus obstruktif disebabkan oleh dua grup besar penyebab dari kondisi intrahepatik dan ekstrahepatik. Tumor pankreas bisa terjadi karena adanya infeksi dari batu empedu. Pemeriksaan darah yang berguna pada kolangitis akut ialah yang menandai adanya inflamasi (meningkatnya leukosit dan/atau meningkatnya C-reactive protein/CRP) dan bukti obstruksi komplit atau parsial duktus biliaris (meningkatnya bilirubin, enzim hepar dan bilier, seperti aspartat alanin aminotransferase, aspartat aminotransferase, alkalin fosfatase dan GGT). Kultur darah sebaiknya dilakukan secepat mungkin. Respon inflamasi yang terjadi pada kolangitis dapat mengakibatkan terjadinya ulkus peptikum maupun gastritis erosive. Hal tersebut dikarenakan pada kolangitis terjadi stres inflamasi yang dapat memicu pengeluaran mediator inflamasi seperti TNF, TNF receptor, IL-1, IL-6, dan IL-10.

Faktor ini menyebabkan overekspresi sitokin yang berakibat kerusakan mukosa gaster. Selanjutnya inflamasi mukosa gaster bertanggung jawab terhadap terjadinya ulkus peptikum. Pada pemeriksaan penunjang ikterus obstruktif terutama pada pemeriksaan laboratorium darah. Perlu diperhatikan jumlah leukosit, bila jumlahnya meningkat, maka berarti terdapat infeksi. Perhatikan juga apakah terdapat peningkatan prothrombin time (PT) atau tidak, karena apabila prothrombin time meningkat, maka perlu dicurigai adanya penyakit hepar, atau obstruksi bilier. Dari hasi penelitian peneliti berpendapat adanya korelasi yang signifikan antara peningkatan kadar leukosit pada ikterus obstruktif yang disebabkan oleh tumor pankreas, dikarenakan ini berhubungan dengan pelepasan mediator inflamasi dimana akan terjadi kadar leukosit serum di darah mengalami peningkatan. Antigen karbohidrat serum 19-9 (CA 19-9) sering digunakan untuk diagnosis dan penilaian prognosis dari neoplasma pankreatobilier. Kadar CA 19-9 >100 U/mL sering menandai adanya penyakit keganasan, terutama sadium awal kanker pankreas. Spesifitas dari kadar CA 19-9 >1000 U/mL untuk kanker pankreas ialah 99\%. Namun, kadar CA 19-9 setinggi $>1000 \mathrm{U} / \mathrm{mL}$ sering juga ditemukan pada beberapa penyakit jinak, seperti batu duktus biliaris komunis, kolangitis akut, pankreatitis akut, diabetes, dan sirosis hepatis

Berdasarkan uji korelasi spearmen diperoleh $p$-value $0,024(\leq 0,05)$ sehingga ha diterima. Maka dapat disimpulkan bahwa terdapat hubungan yang bermakna antara kadar bilirubin total pada penderita ikterus obstruktif yang disebabkan oleh tumor pankreas di Rumah Sakit Abdul Moeloek tahun 2017-2019. Dari hasil penelitian sebelumnya sebagian besar penderita memiliki kadar bilirubin lebih dari normal, terutama pada bilirubin total. Hal ini disebabkan oleh obstruksi pada saluran empedu karena lokasi tumor penderita yang berada pada caput pankreas atau pada lokasi lain selain caput pankreas yang sudah terjadi metastasis hepar atau limfonodi hilus yang menekan saluran empedu. Obstruksi saluran empedu tersebut menyebabkan bilirubin meningkat, terutama bilirubin direk (Auliya, 2015). Bilirubin dibentuk dari pemecahan cincin heme pada metabolisme sel darah merah. Keadaan ini merupakan suatu tanda penting adanya penyakit hati atau kelainan fungsi hati, saluran empedu, dan penyakit darah (khususnya kelainan sel darah merah). Kadar normal bilirubin di dalam serum berkisar antara 0,3-1,0 mg/dl, dan jumlah kadar bilirubin akan dipertahankan oleh keseimbangan produksi bilirubin dengan 
penyerapannya oleh organ hati, konjugasi, dan ekskresi dari empedu. Warna kekuningan sudah dapat terlihat pada daerah sklera serta mukosa sklera jika kadar bilirubin telah mencapai $2-2,5 \mathrm{mg} / \mathrm{dl}$. Sedangkan pada kulit akan terlihat warna kuning pada saat kadar bilirubin telah mencapai $>5 \mathrm{mg} / \mathrm{dl}$. Terjadinya ikterus dapat disebabkan oleh peningkatan dari kadar bilirubin direk (conjugated bilirubin) dan atau kadar bilirubin indirek (unconjugated bilirubin) (Abdoerrachman et al., 2007).

Pada kasus ikterus obstruktif post-hepatik, paling banyak dijumpai pada usia 50-59 tahun yaitu sebanyak 29,3\%. Ikterus obstruktif post-hepatik dapat dijumpai pada perempuan dan laki-laki, dimana pada laki-laki ditemukan sebanyak 65,9\%. Menurut Hatfield et al., kasus ikterus obstruktif paling banyak disebabkan oleh karsinoma kaput pankreas yaitu sebanyak 70\%, 2\% disebabkan oleh karsinoma kandung empedu, dan 8\% disebabkan oleh batu pada saluran empedu (common bile duct). (Brama, 2013). Pada ikterus obstruktif, terjadi obstruksi dari pasase bilirubin direk sehingga bilirubin tidak dapat diekskresikan ke dalam usus halus dan akibatnya terjadi aliran balik ke dalam pembuluh darah. Akibatnya kadar bilirubin direk meningkat dalam aliran darah dan penderita menjadi ikterik. Karena kadar bilirubin direk dalam darah meningkat, maka sekresi bilirubin dari ginjal akan meningkat sehingga urine akan menjadi gelap dengan bilirubin urin positif. Sedangkan karena bilirubin yang diekskresikan ke feses berkurang, maka pewarnaan feses menjadi berkurang dan feses akan menjadi berwarna pucat seperti dempul (acholis). Peningkatan kadar bilirubin indirek lebih sering terjadi akibat adanya penyakit hepatoseluler, sedangkan apabila terjadi peningkatan bilirubin direk biasanya terjadi karena adanya obstruksi pada aliran ekskresi empedu (Sjamsuhidajat, 2010). Ikterus disebabkan karena lokasi tumor yang biasanya pada caput pankreas sehingga menekan saluran empedu dan terjadi obstruksi, yang ditandai dengan peningkatan bilirubin, terutama bilirubin direk. Ikterus dapat terjadi pada kadar bilirubin total minimal $2-2,5 \mathrm{mg} / \mathrm{dL}$. Peningkatan kadar bilirubin yang menyebabkan ikterus pada caput pankreas sering terjadi lebih awal. Ikterus juga dapat terjadi pada lokasi selain caput pankreas stadium lanjut akibat metastasis di hepar atau limfonodi di hilus yang menekan saluran empedu ( Auliya, 2015 ).

\section{Simpulan Dan Saran}

Hasil penelitian menunjukkan bahwa ada korelasi yang baik antaraa kadar leukosit dengan kejadian tumor pankreas ( $\mathrm{p}$-value $=0,047$ ) dan juga menampilkan nilai korelasi data yaitu 0,316. Ada korelasi yang baik antara kadar bilirubin total dengan kejadian tumor pankreas (p-value 0,024) dan juga menampilkan nilai korelasi data yaitu 0,357. Kesimpulannya , peningkatan kadar leukosit dan kadar bilirubin total diiringi juga dengan kejadian ikterus obstruktif yang disebabkan oleh tumor pankreas. Oleh karena itu, diharapkan hasil dari penelitian ini mampu memberikan infrormasi dan ilmu pengetahuan bagi masyarakat, sehingga dapat menekan timbulnya kejadia tumor pankreas. Dan harapkan untuk peneliti selanjutnya untuk menambah wawasan dalam faktor-faktor yang menyebabkan kejadian tumor pankreas.

\section{Daftar Rujukan}

Abdoerrachman, M.H. et al. (2007). Buku Kuliah Ilmu Kesehatan Anak Jilid 2. Jakarta: Bagian Ilmu Kesehatan Anak Fakultas Kedokteran Universitas Indonesia.

Brama, Ragil. (2013). Karakteristik Dan Evaluasi Kadar Bilirubin Direct Pre-Operatif Dan Post-Operatif Pada Pasien Ikterik Obstruksi Post-Hepatik. Jurnal Kedokteran Universitas Jambi.

Guyton, Arthur C dan John E hall. (1997). Fisiologi Gastrointestinal. Dalam : Irawati Setiawan (Editor Bahasa Indonesia) Buku Ajar Fisiologi Kedokteran Edisi 9. Jakarta: EGC. h. 1108-1109 
Norton, J., Bollinger, R. R., Chang, A. E., \& Lowry, S. F. (Eds.). (2012). Surgery: basic science and clinical evidence. Springer.

Hastono. (2007). Analisa Data Statistika Dan Penelitian Dengan Komputer. Jakarta: FKMUI.

Henry, S. A., Prizment, A. E., \& Anderson, K. E. (2013). Duration of diabetes and pancreatic cancer in a case-control study in the Midwest and the Iowa Women's Health Study (IWHS) cohort. JOP: Journal of the pancreas, 14(3), 243.

Kee, Joyce LeFever. (1997). Buku Saku Pemeriksaan Laboratorium dan Diagnostik Dengan Implikasi Keperawatan. Jakarta : EGC.

Ringoringo, Parlin dr. (1990). Atresia Bilier dalam Cermin Dunia Kedokteran No. 86, 1993. Jakarta:Jurnal diunduh dari http://www.kalbe.co.id/files/cdk/files/cdk 086 masalah anak.pdf

Schwarz SM. (2011). Pediatric biliary atresia. [online]. Updated Juni 2011. [cited September 2011]. Available from URL: https://emedicine.medscape.com/article/927029-overview

Smeltzer, S.C., dan Bare, B.G. (2002). Buku Ajar Keperawatan Medikal Bedah Brunner\& Suddarth Edisi 8 Vol. 2. Jakarta: Penerbit Buku Kedokteran EGC.

Sulaiman HA, Akbar HN, Lesmana LA, Noer HMS. (2009). Buku ajar ilmu penyakit hati. Edisi ke-1 (Revisi). Jakarta: Jayabadi.

Sulaiman, Ali. (2007). Pendekatan klinis pada pasien ikterus. In: Aru W Sudoyo, et al. Buku ajar ilmu penyakit dalam Jilid 1. $5^{\text {th }}$ Ed. Jakarta: Penerbitan FKUI; p.420-3.

Yeo, T. P. (2015, February). Demographics, epidemiology, and inheritance of pancreatic ductal adenocarcinoma. In Seminars in oncology (Vol. 42, No. 1, pp. 8-18). WB Saunders. 